\section{E-LOGOS}

ELECTRONIC JOURNAL FOR PHILOSOPHY ISSN 1211-0442

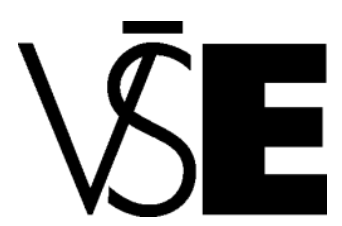

University of Economics

Prague

\title{
Makroekonómia a mylné usudzovanie z časti na celok
}

Miroslav Titze

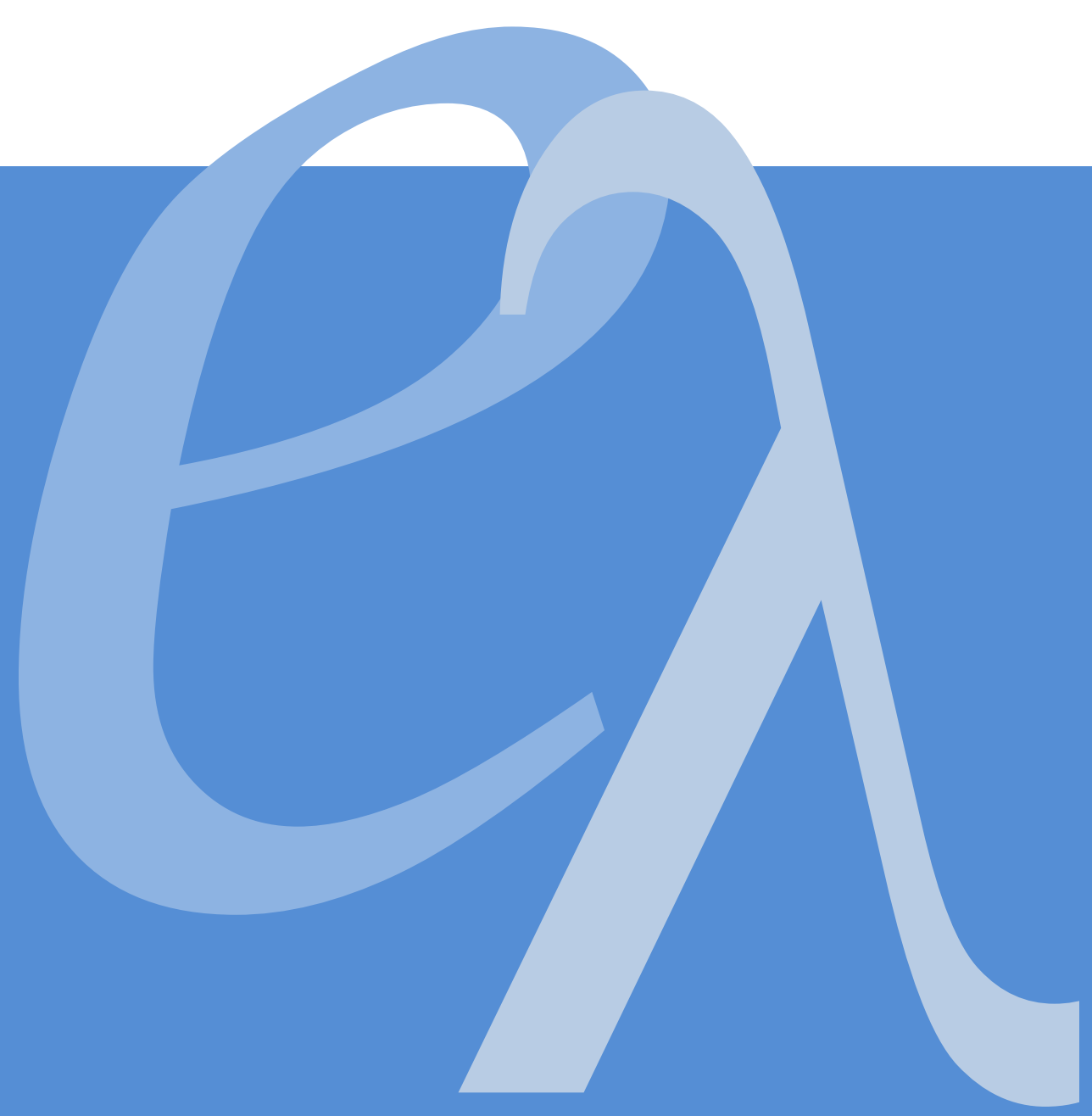




\begin{abstract}
Main goal of the paper is discuss methodological problem in macroeconomy called fallacy of composition. There is important in macroeconomy research to verify content even form to reveal this methodological problem to use right methodology. Fallacy of composition problem is relative strong argument for application of pluralistic methodology in macroeconomy. Fallacy of composiion has wide use in macroeconomy and economic policy. Macroeconomics can avoid fallacy of composition by using balance sheet approach. Nowadays example of economic policy suffered by fallacy of composition is quantitative easing. There is question, why this relatively important methodological problem is on the edge of the methodological research in economy.
\end{abstract}

Keywords: fallacy of composition, macroeconomy, methodology of macroeconomics

\begin{abstract}
Abstrakt
Ciel'om práce je poukázat' na metodologický problém mylného usudzovania z časti na celok v makroekonómii. Pri skúmaní v makroekonómii, je potrebné overovat' obsah i formu, aby sme dokázali tento problém odhalit' a použit' správnu metódu skúmania. Problém mylného usudzovania $\mathrm{z}$ časti na celok je relatívne silný argument pre používanie metodologického pluralizmu pri skúmaní v makroekonómii. Koncept mylného usudzovania $\mathrm{z}$ časti na celok má široké uplatnenie $\mathrm{v}$ makroekonómii $\mathrm{i}$ hospodárskej politike. Metodologickému problému sa dá vyhnút prostredníctvom rozvahového prístupu $\mathrm{k}$ makroekonómii. $\mathrm{V}$ súčasnosti konceptom mylného usudzovania z časti na celok trpí napríklad politika kvantitatívneho uvol'ňovania. Je otázkou, prečo takto závažný metodologický problém zostáva relatívne na pokraji skúmania metodológie v ekonómii.
\end{abstract}

Klíčová slova: mylné usudzovanie z časti na celok, metodológia makroekonómie 


\section{Úvod}

Po vypuknutí globálnej hospodárskej krízy v roku 2008 sa do popredia ekonomických diskusií dostáva makroekonomická teória s rôznymi návrhmi na riešenie krízy. Málo sa už hovorí o metodologickom probléme mylného usudzovania z časti na celok. Makroekonomické opatrenia ovplyvňujú život všetkých, či už pozitívnym alebo negatívnym spôsobom, priamo alebo nepriamo prostredníctvom fungovania spoločnosti, ekonomiky a inštitúcií. Jedinec z individuálneho hl'adiska len t’ažko dokáže ovplyvnit' výrazne makroekonomické fungovanie a je preto závislý na činnosti iných jedincov a fungovaní celej makroekonomiky. Pre vymanenie z krízy musí byt' z praktického hl'adiska aplikovaná vhodná hospodárska politika. Bez pochopenia fungovania makroekonómie je možné, že nebudú prijaté najvhodnejšie opatrenia z pohl'adu rastu produktu, blahobytu, nezamestnanosti, ziskovosti podnikov, inflácie a ostatných ekonomických veličín. Hospodárska kríza dáva opät' priestor i k znovu otvoreniu metodologickej otázky medzi tradičnou keynesiánskou makroekonómiou a klasickou makroekonómiou hlavného prúdu známejšou ako „paradox úspor", ktorý je praktickým príkladom všeobecnejšieho metodologického problému mylného usudzovania $z$ časti na celok. Hlavným ciel'om práce je poukázat’ na všeobecný problém mylného usudzovania z časti na celok $v$ makroekonomickej teórii, čo sa následne prejavuje do navrhovaných praktických opatrení hospodárskej politiky. Práca sa snaží odhalit' v makroekonomickej teórii i možný spôsob, akým by sa dalo problému zamedzit'. Celá klasická makroekonómia je prakticky zahltená množstvom prípadov mylného usudzovania z časti na celok. Je až zarážajúce, že tomuto metodologickému problému je v ekonomickej odbornej literatúre venovaná len vel'mi malá pozornost', aj napriek tomu, že sa jedná o vel'mi závažný metodologický problém. Pomerne silná diskusia problému mylného usudzovania z časti na celok sa rozvíjala od sedemdesiatych rokov 20. stor. v medzinárodnom obchode pod vplyvom začínajúcej globalizácie, vstupom Číny do WTO a posunom nízkopríjmových krajín v Južnej Ázii k exportne orientovaným stratégiám spojených s výrobou manufaktúrne náročných výrobkov. Jednalo sa o tzv. "adding-up“ problém. Čo bolo výhodné pre malých exportérov v pomerne izolovanom prostredí, nemuselo platit' pre skupinu vel'kých exportérov, konajúcich v rovnakom čase. Bližšie o probléme píše napr. J. Mayer (2003), W. A. Kerr (2009) a d’alší. Z makroekonomického hl'adiska je možným ospravedlnením nezáujmu vel'mi zriedkavý výskyt problému mylného usudzovania z časti na celok a to najmä pri závažných systémových ekonomických problémoch, kde dochádza k zmene makroekonomického optimalizačného správania $\mathrm{z}$ maximalizácie úžitku na minimalizáciu dlhu na ktoré poukazuje napríklad R. C. Koo (2009). Jednou z mála škôl, ktorá berie v úvahu mylné usudzovanie z časti na celok a priamo naň upozorňuje sú post-keynesiánci. Práca sa zaoberá konceptom mylného usudzovania z časti na celok zo všeobecného hl'adiska v makroekonómii, nerozoberá detailne jednotlivé praktické príklady nakol'ko by sa práca dostala mimo vytýčený ciel'. 
Prvá čast' práce sa zaoberá teoretickým vymedzením mylného usudzovania z časti na celok a jeho taxonómiou. Tento druh omylu je všeobecný a nevyskytuje sa iba v ekonómii. Mylné usudzovanie z časti na celok je možné l'ahko zamenit’ i s inými pridruženými metodologickými problémami.

Druhá čast' práce poukazuje na jednotlivé prípady mylného usudzovania z časti na celok v makroekonómii. Diskutuje problém mylného usudzovania z časti na celok v súvislosti prehliadania efektu prepojenosti rozváh ekonomických subjektov. Prípad mylného usudzovania z časti na celok rozširuje do oblasti hospodárskej politiky.

Tretia čast' práce poukazuje na netradičnú menovú politiku praktikovanú centrálnymi (kvantitatívne uvol’ňovanie) ako možný príklad hospodárskej politiky trpiacej problémom mylného usudzovania z časti na celok.

\section{Mylné usudzovanie z časti na celok a jeho taxonómia}

Mylné usudzovanie vzniká pri logickom uvažovaní a používaní argumentov. Klasická makroekonómia je postavená na logickom vyvodzovaní záverov ohraničených v logickom čase. Prvú systematickú štúdiu a taxonómiu omylov vytvoril Aristoteles v jeho diele v pôvodnom názve De Sophisticis Elenchis (preklad On Sophistical Refutation, (2001)) v ktorom rozoznával trinást' omylov. Aristoteles zaradil tento druh omylu ${ }^{1}$ medzi verbálne. Mylné usudzovanie z časti na celok vzniká v prípade, ak niečo platí pre určitú čast' celku, avšak pre celok zložený z týchto častí to už neplatí. Zarad'uje sa medzi neformálne typy omylov, pri ktorých záleží aj na obsahu argumentu. Zmysel neformálnych typov omylov je nesprávny z epistemologických, dialektických alebo pragmatických dôvodov. W. L. Rowe (1962) poukazuje na to, že problém mylného usudzovania z časti na celok odhalíme až ex post po tom ako overíme vlastnosti celku zloženého z jednotlivých častí. Analýza obsahu nám pomáha určit', či sa jedná o pravdivé alebo nepravdivé argumenty a identifikovat' mylné usudzovanie z časti na celok. V prípade, že máme danú formu pre účely identifikácie, nemôžeme ju samu o sebe považovat’ za nesprávnu, to nám môže potvrdit' až obsah. To znamená, že forma a obsah sa nevylučujú, ale skôr dopĺn̆ajú. Vel'mi dobre je to vidiet' na príkladoch mylného usudzovania z časti na celok uvedených nižšie. Existujú dva druhy prípadov mylného usudzovania z časti na celok podl'a W. L. Roweho (1962). Prvý typ vzniká v prípade, že vyvodzujeme závery $\mathrm{z}$ určitej vlastností individuálnych členov celku na celú skupinu (member-class fallacy of composition). Všeobecný príklad môže byt' nasledujúci

"Jednotlivec XY má charakteristické vlastnosti $A, B, C$. Potom aj celá skupina zložená z jednotlivcov XY má charakteristické vlastnosti $A, B, C . "$

${ }^{1}$ Pod pojmom omyl práca d'alej rozumie tie, ktoré vyplývajú z logickej formy argumentácie a nie omyly vyplývajúce z účelu argumentácie 
Nie vždy však nutne musí nastat' situácia, ked' usudzovanie z časti na celok je nesprávne. $\mathrm{V}$ prípade, že by aj $\mathrm{v}$ skutočnosti mala celá skupina charakteristické vlastnosti $A, B, C$, potom je výrok pravdivý. Na druhú stranu nič nezaručuje, že aj skupina tvorená z prvkov s charakteristickými vlastnost'ami A,B,C bude mat' rovnaké vlastnosti ako prvky a nemôže sa správat' inak alebo mat' iné vlastnosti. V tom prípade hovoríme o mylnom usudzovani z časti na celok. Musíme preto d'alej skúmat' obsah argumentácie pri zvolenej argumentačnej forme.

Druhý typ vzniká v prípade, že vyvodzujeme závery z časti celku na celý celok (part-whole fallacy of composition). Všeobecný príklad je nasledujúci:

"Čast' celku má vlastnosti A,B,C. Potom aj celok obsahujúci dané časti má charakteristické vlastnosti $A, B, C . "$

V prvom prípade sa jedná o interakciu medzi osobami, v druhom prípade sa jedná napríklad o určité predmety tvorené z častí. Toto delenie je z hl'adiska častí na životné (member-class) a neživotné (part-whole). Opät' to platí obdobne ako v prvom príklade, že celý predmet sa môže stotožňovat' s čast'ou celku alebo nie. ${ }^{2}$

Usudzovanie z časti celku na celok sa využíva i pri štatistickom testovani hypotéz z výberových šetrení. Jedná sa o obsahové overenie (štatistické) formálneho logického postupu, ked' skúmame, či vlastnosti určitej časti celku reprezentujú celý celok na určitej hladine významnosti pri určitom pravdepodobnostnom rozdelení. V prípade, že rozdiel medzi výberovou skupinou a celkom nie je štatisticky významný, daný výrok môžeme na určitej hladine významnosti zovšeobecnit' na celok. Pri využití testovania hypotéz môžeme l'ahko skĺznut' i k pridruženému problému unáhleného zovšeobecňovania (hasty generalization), ked' k zovšeobecneniu používame malý rozsah súboru ${ }^{3}$. Nastávajú i d’alšie štatistické problémy pri testovaní hypotéz, čo sa prenáša d'alej do určovania kauzality v ekonometrii.

Vyššie predstavenú základnú taxonómiu mylného usudzovania z časti na celok podrobnejšie rozoberá d'alej napr. W. L. Rowe (1962). Poukazuje, že nie vždy musíme pri vyvodzovaní z časti na celok spáchat' chybu. Problém nastáva vtedy, ked' uvažujeme o častiach celku izolovane bez ich vzájomnej interakcie. Správnost' výroku môžeme dosiahnut' zmenou predpokladu z ktorého vychádzame. Často krát je problém mylného usudzovania z časti na celok zamieňaný s problémom nejednoznačnosti (fallacy of ambiguity) podl'a W. L Roweho (1962). Nejednoznačnost' je spôsobená relatívnymi termínmi ako napr. malý, dobrý, l'ahký na rozdiel od jednoznačných termínov ako napr. čierny, kovový atd'. Nejednoznačnost' relatívnych termínov používa iné kritéria pre hodnotenie jednotlivých častí a celku čo spôsobuje mylné usudzovanie

\footnotetext{
2 Aj ked'sa o takomto delení na životné a neživotné prípady mylného usudzovania autor článku L. Rowe (1962) výslovne nezmieňuje, podl'a môjho názoru to implicitne vyplýva z jeho článku

${ }^{3} \mathrm{~V}$ testovaní hypotéz sa nám štatisticky prejaví robustnost' výberu $\mathrm{v}$ stupňoch volnosti a následne i v ostatných testoch obsahujúcich stupne vol'nosti
} 
$z$ časti na celok. Nie všetky prípady mylného usudzovania z časti na celok možno stotožnit' s problémom nejednoznačnosti. W. L. Rowe (1936) uvádza na str. 91 nasledujúci príklad: „všetky časti tohto obrázku sú trojuholníkové, potom aj obrázok je trojuholníkový." Do praktického príkladu si to môžeme previest', ked' máme dva trojuholníky a zložíme z nich výsledný štvorec. Úvahy tohto typu, kde premisa a záver majú rovnaký zmysel považuje za čisté príklady mylného usudzovania z časti na celok. Nedajú sa klasifikovat' ako problém nejednoznačnosti (fallacy of ambiguity). Tvrdí, že nie všetky prípady mylného usudzovania z časti na celok sa dajú vysvetlit' týmto „verbálnym“ problémom. Otázkou zostáva, či rovnaká taxonómia platí pre mylné usudzovanie $\mathrm{z}$ časti na celok typu v prípade celkov pozostávajúcich z osobností alebo neživotných častíc.

Opakom mylného usudzovania z časti na celok je symetrický prípad, ked' hovoríme, že ak niečo platí pre celok, potom to platí aj pre jednotlivé časti celku alebo proky. $\mathrm{V}$ ekonómii by tento prípad nastal $\mathrm{v}$ opačnom garde, ked' $\mathrm{z}$ chovania makroekonomického systému odvodzujeme správanie jednotlivcov. Metodologické problémy mylného usudzovania z časti na celok a z celku na časti, ktoré sú súčast́ou klasickej a keynesiánskej makroekonómie dávajú priestor pre vzájomnú spoluprácu a dopíňanie sa. Nevýhodou je, že syntézu týchto dvoch metodologicky odlišných makroekonómii komplikuje nemožnost' vytvorenia jednotnej makroekonomickej teórie založenej na jednotnej metodológii. Vel’ká neoklasická syntéza na metodologický problém reaguje oddelením neokeynesiánskej makroekonómie pre analýzu krátkodobých ekonomických procesov a neoklasickej zložky slúžiacej na analýzu dlhodobých ekonomických procesov, pričom sa bežne neoklasická zložka interpretuje ako všeobecná teória.

\section{Mylné usudzovanie z časti na celok $v$ makroekonómii}

Mylné usudzovanie z časti na celok je možné zaradit’ do nevyriešeného sporu o metódu medzi metodologickým individualizmom a metodologickým kolektivizmom. V ekonómii charakterizujú T. R. Jain, O. P. Khana (2006) metodologický problém mylného usudzovania z časti na celok charakterizovaný ako prípad, ked' je niečo dobré pre jednotlivca a zároveň je to nevhodné pre celú ekonomiku. Ekonomicky to, čo platí pre individuálne ekonomické subjekty (firmy, domácnosti) nemusí platit' pre ekonomiku ako celok (makro ekonomiku). Vo vedeckej makroekonómii sa mnohým problémom mylného usudzovania z časti na celok vyplývajúcich z nejednoznačnosti (fallacy of ambiguity) môžeme vyhnút' odmietnutím použivat' normatívne a hodnotiace súdy a z nich vychádzajúce relatívne pojmy (dobrý, zlý, atd'.). Tým prijmeme metodologický pozitivizmus M. Friedmana (1997). Máme v makroekonómii skúmat' najskôr správanie skupiny (v zmysle systému tvoreného prvkami), alebo začat' od skúmania prvkov (jednotlivcov), výsledkom ktorých je fungovanie systému? V ekonómii existujú z metodologického hl'adiska 
vedl'a seba dva druhy makroekonómie líšiace sa svojou metódou skúmania. Klasická makroekonómia vychádza $\mathrm{z}$ princípu maximalizácie úžitku jednotlivcov agregovaného na úrovni hospodárstva. Pre agregovanie používa reprezentatívnu firmu na strane ponuky a reprezentatívnu domácnost' na strane dopytu, výsledkom ktorých je akýsi kompozitný statok. Primárne sa zameriava na ekonomický a finančný tok. Je zaujímavé, že aj ked' nepriamo o mylnom usudzovaní z časti na celok sa zmienil aj jeden zo zakladatel'ov klasickej ekonómie A. Smith (1776):

"What is prudence in the conduct of every private family, can scarce be folly In that of a great kingdom" (A. Smith, 1776, str. 364)

A. Smith položil základ bohatstva na "neviditel'nej ruke“ trhu, kde jedinci maximalizujú svoj vlastný prospech. Tým maximalizujú i prospech celého národa. Obsahuje vlastný záujem problém mylného usudzovania z časti na celok? Je otázkou nakol'ko si A. Smith tento metodologický problém uvedomoval a bral ho v úvahu.

V utilitarisitkom prípade J. S. Milla (1863) maximalizujú blahobyt alebo úžitok (št́astie) jednotlivci, potom i na úrovni hospodárstva musí byt' maximalizovaný blahobyt (št'astie) spoločnosti. Otázkou je či musí byt' táto podmienka splnená vždy? V prípade, že maximalizácia úžitku jednotlivca ovplyvňuje pozitívne maximalizáciu úžitku iných jednotlivcov potom i celkový agregovaný úžitok je maximalizovaný a problém mylného usudzovania z časti na celok môžeme zamietnut'. V prípade, že maximalizácia úžitku jednotlivcov spôsobí stratu úžitku u iných jednotlivcov výsledok závisí už na výslednom efekte.

J.M. Keynes (1936) položil na princípe mylného usudzovania z časti na celok teóriu pod spotreby a permanentného zaostávania dopytu za ponukou. J. M. Keynes (1936) píše:

"As this prudent economy, which some people call Saving, is in private families the most certain method to increase an estate, so some imagine that, whether a country be barren or fruitful, the same method if generally pursued (which they think practicable) will have the same effect upon a whole nation, and that, for example, the English might be much richer than they are, if they would be as frugal as some of their neighbours. This, I think, is an error." (Keynes, 1936, str. 355)

V ekonómii sa mylné usudzovanie z časti na celok presadilo v podobe teórie známej ako paradox úspor. V prípade, že všetci spotrebitelia začnú simultánne sporit' viac a nič nebude nahrádzat' stratu spôsobenú zníženými výdajmi, spotrebitelia trpia viac, pretože národný prijem sa zníži vd’aka poklesu spotreby, zvýši sa nezamestnanost' a spotrebitelia $\mathrm{v}$ konečnom dôsledku usporia menej, pretože úspory sú funkciou prijmu.

$\mathrm{V}$ prípade paradoxu úspor sa jedná z hl'adiska kauzality o spätný vplyv ekonomického systému na správanie jednotlivcov z dynamického hl'adiska. V makroekonómii vznikli i d'alšie teórie a koncepty založené na problematike 
mylného usudzovania z časti na celok:, paradox zvýšenej pracovitosti G. Eggertssona (2010), paradox oddlžovania R. C. Koo (2001), G. Eggertsson, P. Krugman (2010) atd'. R. C. Koo (2001) aplikuje koncept mylného usudzovania z časti na celok na japonskú stagnáciu:

"The weakness of the economy depresses asset prices even further, forcing Japanese companies and households to take even more craconian measures to repair their balance sheets. The result has been a vicious cycle brought about by the so-called fallacy of composition, taht is, everybody is doing the right thing from their individual perspective, but the combined result of their efforts has been the opposite of their aggregate goal." (R. C. Koo, 2001)

Problém v makroekonómii nastáva hlavne pri nepriaznivom vývoji ekonomiky a s vypuknutím krízy sa oživil aj koncept mylného usudzovania z časti na celok. Naskytuje sa otázka, akým spôsobom vyriešit' problém mylného usudzovania z časti na celok v makroekonómii a navrhnút následné hospodárske opatrenia na prekonanie krízy? Prvým riešením je odmietnutie agregácie a agregovaných veličín, čím by stratila makroekonómia celý svoj základ a zmysel. Agregovaný úžitok a veličiny odmieta metodológia rakúskej školy (praxeológia), pre ktorú sú kolektívne entity iba abstrakciami, nemôžu mysliet' ani jednat'. Jednajú iba individuálne subjekty, ktorých úžitok nemožno zmerat’ a ani agregovat'. Vychádza z prísneho metodologického individualizmu.

"We must conclude then that there is no such thing as total utility; all utilities are marginal. In those cases where the supply of a good totals only one unit, then the "total utility" of that whole supply is simply the marginal utility of a unit the size of which equals the whole supply. The key concept is the variable size of the marginal unit, depending on the situation." (M. N. Rothbard, 1956)

Rakúska škola obchádza problém mylného usudzovania z časti na celok tým, že do tvrdenia pridáva i d'alšiu podmienku, pri ktorej je úžitok jednotlivca maximalizovaný. Tou je dobrovol'nost' zmeny. Vychádza z toho, že dobrovol'ná zmena vždy zvyšuje úžitok obidvom zúčastneným stranám. Môžeme si to ukázat' na danom príklade: Predstavme si subjekt (vlastníka firmy), ktorý produkuje určitý statok $X$, výsledkom ktorého je obrovské znečistenie ovzdušia, ktoré znižuje úžitok ostatným obyvatel'om a zvyšuje úžitok iba spotrebitel'om kupujúcim daný statok. V tomto prípade máme dvoch, ktorých úžitok sa zvýšil a jedného, ktorého úžitok sa znížil. Odmietnutie agregácie nám neumožňuje porovnat' ako na tom celok $v$ skutočnosti je a nedokážeme potvrdit' ani vyvrátit' problém mylného usudzovania z časti na celok. Odmietneme agregáciu a porovnanie úžitkov, alebo znečistený vzduch budeme považovat' za statok, ktorí ostatní l'udia spotrebovávajú nedobrovol'ne.

Ďalšou možnost'ou je zmenit' formu prístupu $k$ metodológii makroekonómie. Metodologický kolektivizmus sa javí ako vhodná forma popri metodologickom individualizme. Tu sa dostávame nepriamo k najväčšiemu sporu o metódu v ekonómii 
pod názvom Methodenstreit. ${ }^{2}$ Tieto dve metódy je možné vhodne kombinovat' a nemusia sa vždy vylučovat'.

Riešením je možnost' l'ubovol'ne zmenit' obsah (ekonomickú teóriu), aby vyhovovala forme. To znamená prijat' koncept mylného usudzovania z časti na celok. Vyššie uvedený príklad znie potom nasledujúco:

"Časti celku majú vlastnosti A,B,C. Celá skupina obsahujúca časti tohto celku má charakteristické vlastnosti $E, F, G . "$

Týmto spôsobom sme dosiahli správnost' výroku v prípade, že celok má iné vlastnosti ako individuálne subjekty. J.M. Keynes (1936), ale i ostatní ekonómovia vychádzajúci $\mathrm{z}$ mylného usudzovania $\mathrm{z}$ časti na celok poukazujú na tento metodologický problém v makroekonómii. Oponenti paradoxu úspor súhlasia práve so zmenou obsahu, ked' rast úspor spôsobí zníženie príjmov, ale klesajúce ceny zaručia návrat do pôvodnej rovnováhy medzi dopytom a ponukou (Sayov zákon trhu). Rast úspor zníži úrokovú mieru a zvýšia sa investície a dopyt. ${ }^{5}$

Mylné usudzovanie z časti na celok má odraz i v praktickej hospodárskej politike. Opät' môžeme pokračovat' v našom jednoduchom všeobecnom príklade vychádzajúceho z určitej časti celku, ktorý môžeme rozšírit':

"Celok tvorený z individuálnych osobností s vlastnostami $A, B, C, E, F, G$ má charakteristické vlastnosti $A, B, C$." V prípade, že pridáme do skupiny jednotlivcov s vlastnostami $A, B, C$ (urobíme určité hospodárske opatrenie a tým zmeníme vlastnosti, správanie...) alebo zmeníme čast' skupiny jednotlivcov s vlastnostami $E, F, G$ na jednotlivcov s vlastnost'ami $A, B, C$ potom sa zoýši pravdepodobnost', že charakteristické vlastnosti skupiny budú $A, B, C$.

Príklad funguje i v opačnom garde, ked' pridáme alebo zmeníme čast' celku s vlastnostami $A, B, C$, na čast' skupiny s vlastnost́ami $E, F, G$, potom je menšia pravdepodobnost', že bude mat' celok vlastnosti A,B,C. Opät' si to môžeme previest' do Keynesovho (1936) alebo Kooho (2008) príkladu proti cyklickej fiškálnej politiky v čase hospodárskej krízy. V prípade, že budú všetky ekonomické sektory sporit' (prípadne oddlžovat' sa) vrátane vlády, potom sa zhorší recesia na rozdiel od prípadu, že sa bude určitý sektor alebo subjekty chovat' proti cyklicky. ${ }^{6}$ Klasická makroekonómia vychádzajúca z metodologického individualizmu akoby zabúdala na to, že jednotlivé ekonomické subjekty svojím individuálnym správaním ovplyvňujú iné subjekty a

\footnotetext{
${ }^{4}$ Viac o probléme Methodensteitu je možné sa dozvediet’ v knihe Spor o metódu medzi rakúskou školou a nemeckou historickou školou (M. Loužek, 2001)

${ }^{5}$ Ciel'om práce nie je ekonomicky riešit' konkrétny problém spojený s paradoxom úspor alebo iné paradoxy vyplývajúce z mylného usudzovania z časti na celok, preto ekonomickému rozboru nie je venovaná väčšia pozornost'

${ }^{6} \mathrm{Z}$ pohl'adu rozváh vznikne situácia, ked' subjekty, ktoré budú mat' záujem prispôsobit' svoje rozvahy a oddlžit' sa, nebudú mat' možnost' na úkor koho by sa oddlžili, ked' sa na hospodárstvo budeme pozerat' z podvojného hl'adiska
} 
systém7 ${ }^{7}$ ktorý ich spätne ovplyvňuje: B. Mitchell (2010) píše o návrhoch klasickej ekonómie pri riešení nezamestnanosti $\mathrm{v}$ prípade mylného usudzovania $\mathrm{z}$ časti na celok: „čo sa môže stat na individuálnej úrovni, nemusí platit’ v prípade, že sa ekonomické subjekty chovajú rovnakým spôsobom (stádovo) ...v zmysle navrhnutých riešení nezamestnanosti klasickou makroekonómiou presadzujúci veria, že jedna firma môže byt' schopná znízit náklady znížením miezd pre zamestnancov, pretože ich dopyt nebude ovplyonený a mohli by prijat viac zamestnancov. Avšak chyba je v tom, že nevidia, že ostatné firmy urobili rovnakú vec, celkové výdaje sa dramaticky znižia a zamestnanost' tak isto"8 Náš príklad môžeme d'alej rozšírit' do roviny diskusie ohładom obsahovej stránky metodologického problému mylného usudzovania z časti na celok a určovania príčin, dôsledkov a vzájomných závislostí na mikroekonomickej a makroekonomickej úrovni:

"Časti celku majú vlastnosti A,B,C. Celá skupina obsahujúca časti tohto celku má charakteristické vlastnosti E, F,G. Charakteristické vlastnosti skupiny E, $F, G$, spôsobujú d'alšie príciny $H, I, J$, ktoré ovplyvňujú pôvodnú skupinu spôsobom $K, L, M$ do budúcnosti atd'..." (...možno pokračovat' rôznymi obmenami vztáhov medzi prokami a systémom zložených $z$ prokov...)

V tom prípade sa už dostávame do problému s určovaním vzájomných kauzalít a pravdepodobností nielen $\mathrm{v}$ teoretickej rovine ale i v praktickej rovine (štatistickej) a do diskusií ohl'adom obsahu, pričom náš ústredný metodologický problém zostáva nevyriešený. Uvažujeme o jedincoch už v interakcii s fungovaním systému.

Ked'že v ekonomike v skutočnosti jednajú iba jednotlivci, každý robí to, čo je z ich individuálneho pohl'adu najvhodnejšie, bez ohl'adu na ostatných (aspoň predpokladajme, že ekonomické subjekty sa chovajú egoisticky podl'a Smithovej neviditel'nej ruky v prípade vel'kých skupín ako je makro ekonomika). $\mathrm{V}$ tom prípade, pri nepriaznivých podmienkach vývoja ekonomiky, z pohladu individuálnych subjektov je racionálne znižovat' spotrebu, viac sporit', oddlžovat' sa, znižovat' náklady firmy atd'. Len t'ažko uspeje $\mathrm{z}$ individuálneho hl'adiska argument, že $v$ konečnom dôsledku je to pre nich nevýhodné a celú situáciu si ekonomické subjekty ešte zhoršujú. P. Krugman (2012) tak isto poukazuje na previazanost' ekonomických subjektov, ked' tvrdí, že sa často zabúda na to, že výdaj jedného subjektu je zároveň príjem druhého subjektu.

Alchýmia racionálneho chovania je $\mathrm{v}$ tom, že $\mathrm{z}$ individuálneho hladiska uskutočňujú ekonomické subjekty správnu vec (racionálnu), ale ked’že sa chovajú

\footnotetext{
${ }^{7}$ Je otázkou prečo by sme mali k individuálnym ekonomickým subjektom pristupovat' izolovane bez interakcie s ostatnými ekonomickými subjektmi. Je zrejmé, že takmer každá zmena má dve strany a potom ako vhodné zachytenie sa odporúča sledovat' zmeny v rozvahách subjektov, kde budeme mat' zobrazené dopady na obidva subjekty a z toho vyplývajúcu vzájomnú interakciu

8 Tu vstupujeme do d’alšieho metodologického problému či sa máme na individuálne subjekty a ich rozhodovanie pozerat' z autonómneho hl'adiska alebo v interakcii s ostatnými ekonomickými subjektmi (metodologický individualizmus vs. metodologický kolektivizmus)
} 
všetky ekonomické subjekty stádovo, vracia sa im to naspät' a v konečnom dôsledku sa prehlbuje recesia a ich problémy. Týmto spôsobom je posilňovaný hospodársky cyklus. Ekonomické subjekty nejednajú izolovane, ale existuje medzi nimi určitá závislost', ktorá po agregácii spôsobuje ovplyvňovanie jednotlivca makroekonómiou. V prípade, že vychádzame z metodologického individualizmu, tak dopad zvýšenia úspor jedného subjektu na celý systém je zanedbatel'ný a prehliadam spätný dopad systému na jednotlivé ekonomické subjekty pri stádovitom chovaní. Podobné je to ako pri vol'bách. Ako dokáže môj jediný hlas ovplyvnit’ výsledky volieb? Z ekonomického hl'adiska subjekty porovnávajú náklady a výnosy svojho chovania. Firma, ktorá sa rozhodne nezoštíhl'ovat' zamestnanost' a produkciu v čase krízy a nedostatočného odbytu by sa chovala „neracionálne“ pretože jej náklady by boli príliš vysoké oproti spätným výnosom, ktoré by mohla firma získat', v prípade, že ostatné firmy prepúštajú a zoštíhl'ujú produkciu. $\mathrm{Z}$ individuálneho pohl'adu sú prehliadané makroekonomické efekty, pretože sú strašne malé a majú nekonečné malý dopad na ekonomiku. Práve prehliadnutie tohto malého zanedbatel'ného efektu na celý systém z individuálneho pohl'adu spôsobuje mylné usudzovanie z časti na celok v klasickej makroekonómii. J.M. Keynes (1936) navrhoval, aby do tohto procesu vstúpila vláda a zmierňovala stádovité chovanie prostredníctvom uskutočňovania proti cyklickej politiky9 . Vzájomná závislost' jednania medzi jednotlivými subjektmi spôsobuje i d'alšie metodologické problémy v klasickej ekonómii vyjadrujúce vzájomné vzt’ahy nezávislými krivkami.

Nemajú náhodou autori (J. M. Keynes, R. C. Koo, K. Boulding a d’alší) poukazujúci na metodologický problém mylného usudzovania z časti na celok spoločný pohl'ad na makroekonomické javy prostredníctvom zmien v rozvahách ekonomických subjektov prostredníctvom ktorých charakterizujú v ekonomike tok. L. R. Wray (1997) cituje K. Bouldinga (1971):

"The marginal analysis...is most instructive in dealing with the theory of the firm and with the demand, supply, and pricing of particular products and particular factors of production. It is not particularly helpful in dealing with the aggregates of the system, because its use is constantly likely to involve us in fallacies of composition" (L. R. Wray, 1997, str. 460)

Definitívne riešenie problému mylného usudzovania z časti na celok ponúka $K$. Boulding (1950) o ktorom píše L. R. Wray (1997). Dynamický pohl'ad na ekonomické subjekty z pohl'adu rozváh poskytuje makroekonómii mikroekonomické základy v ktorých firma nie je iba „bezduchá“ hospodárska jednotka, ktorá nakupuje vstupy a produkuje výstupy. Má svoju kapitálovú štruktúru, dlhy, štruktúru aktív, pasív atd'. Princíp makroekonómie založil na dynamickom procese pohybujúcich sa rozváh

${ }^{9}$ J.M. Keynes (1936) navrhoval anti cyklickú hospodársku politiku, v čase hospodárskej krízy navrhoval podporu hospodárstva prostredníctvom rozpočtového deficitu, naopak v čase hospodárskeho vzostupu navrhoval hromadit' rozpočtový prebytok 
ekonomických subjektov. Princíp dynamických rozváh pozostáva z toho, že ekonomický subjekt sa snaží prispôsobit' svoju rozvahu do ideálneho stavu z pohladu individuálneho subjektu, tým indukuje zmeny v rozvahe d'alšieho subjektu a kolobeh pokračuje až pokial' ekonomické subjekty nedosiahnu svoju želanú rovnováhu. L. R. Wray (1997) píše:

"The 'moving picture' of balance sheets throught time captures the macroeconomic flows that are the primary preoccupation of convetnional economics but without the danger of fallacy of composition" (L. R. Wray, 1997, str. 450)

Týmto spôsobom zachytáva L. R. Wray vzájomnú interakciu medzi jednotlivými ekonomickými subjektmi. Významnost' vzájomnej interakcie medzi jednotlivými rozvahami ekonomických subjektov možno vidiet' napríklad $v$ ohrození finančnej stability jednou inštitúciou. Jedná sa o problém, v ktorom je inštitúcia "príliš vel'ká, aby skrachovala“. Prostredníctvom krachu jednej systémovo dôležitej inštitúcie môže dôjst' prakticky $\mathrm{k}$ pádu celého finančného systému nakol'ko rozvahy jednotlivých inštitúcií sú vzájomne prepojené. Od vel'kosti inštitúcie závisí možná významnosté ovplyvnenia rozváh ostatných ekonomických subjektov. Pomerne novou metódou skúmania finančnej stability sa stalo používanie tzv. teórie grafov, ktorá skúma chovanie subjektov s ohl'adom na vzájomnú interakciu. Jednotlivé subjekty sú vzájomné prepojené prostredníctvom obchodných aktivít. V súčasnosti sa teória grafov používa pre analyzovanie medzibankového nezaisteného trhu, ktorý je zo svojej podstaty založený na dôvere a vzt'ahu medzi systémovo dôležitými inštitúciami a tými, ktorých krach neohrozí robustnost' medzibankového trhu.

Makroekonomiku môžeme chápat' ako agregované rozvahy ekonomických subjektov alebo sektorov podl'a určitých dôležitých ekonomických charakteristických vlastností, ktorými sa v tržnej ekonomike vyznačujú. Agregované makroekonomické rozvahy dokážu vel'a napovedat' aj o mikroekonomickom chovaní subjektov. Makroekonómia založená na agregovaných rozvahách má tak aj svoje mikroekonomické základy. Národné účty dokážu ukázat', ktoré chovanie u ekonomických subjektov prevládlo po agregácii. Štatistiky národných účtov zaznamenali prudký vývoj od osemdesiatych rokov a vd'aka informatizácii spoločnosti sú čoraz presnejšie a viac sa približujú vyčerpávajúcemu šetreniu. Z národných účtov dokážeme vyčítat' práve relatívne štrukturálne zmeny aj $\mathrm{v}$ mikroekonomickom chovaní jednotlivých sektorov. Agregované rozvahy sú v súčasnosti už súčast'ou národného účtovníctva a získavajú čoraz väčší význam i v ekonomickej štatistike mimo národných účtov (napr. zverejňujú sa už agregované rozvahy za bankový sektor, obchodníkov s $\mathrm{CP}$, atd'.).

Koncept mylného usudzovania z časti na celok podporuje metodologický pluralizmus, nakol'ko obsah môže byt' zhodný s použitou metódou skúmania, ale i nemusí. Práve $\mathrm{z}$ vyhranenosti voči používaniu určitých metód v ekonómii môžeme l'ahko skíznut' 
k metodologickým omylom. Mylné usudzovanie z časti na celok je dostatočne silný argument pre používanie viacerých metód $\mathrm{v}$ makroekonómii, pričom metódy sa môžu vhodne i doplňovat'. Ako píše M. Loužek (2001, str. 196): „Vol'ba metodologického individualizmu alebo kolektivizmu ako nástroja pre analýzu spoločenskej či ekonomickej skutočnosti vždy závisí na type problému, ktorým sa zaoberáme. Primárny je vždy problém. Metódu odvodzujeme od problému a nie problém od metódy. Metodologicky sa dopredu obmedzovat" - znamená apriórne vylučovat niektoré problémy zo sociálnych vied." Proti argumentom zostáva opak mylného usudzovania z časti na celok (fallacy of division), ked' niečo, čo platí na makroekonomickej úrovni, neplatí pre jednotlivé ekonomické subjekty (usudzujeme z celku na časti). Pri vyvodzovaní makroekonomických záverov je vhodné pamätat' na tieto dva symetrické metodologické problémy.

\section{Kvantitatívne uvol'ňovanie - príklad súčasnej hospodárskej politiky obsahujúci problém mylného usudzovania z časti na celok}

Naprieč ekonomickými školami nájdeme len málo, ktoré sa výslovne zmieňujú o probléme mylného usudzovania z časti na celok. Možno ho nájst' u niektorých autorov prirad'ujúcich sa k post-keynesiánskemu prúdu ekonómie ako B. Moore alebo M. Lavoie. J. Koderová, Havel, Sojka (2008, str. 201) citujú M. Lavoieho (1992, str. 192): "stúpajúca krivka ponuky úverových peňazí nemôže byṫ odôvodnená na základe preferencie likvidity bánk. Tí, čo zastávajú takýto názor na endogenitu peňazí, musia nakoniec spoliehat' na neakomodatívne chovanie centrálnej banky a že úrokovú mieru vždy nebude stabilizovat'. $V$ prípade, že sa úroková miera zoyšuje je tomu preto, že sa tak rozhodla centrálna banka. Existuje rozdiel medzi správaním sa bankového sektoru z individuálneho hl'adiska a $\mathrm{z}$ makroekonomického hl'adiska. Likvidita hrá rozdielnu úlohu z mikroekonomického a makroekonomického hl'adiska. Jednotlivé firmy čelia stúpajúcej ponuke úverov na rozdiel od makroekonomickej úrovne. Zhruba v posledných dvoch desat'ročiach sa v ekonomike vyostrila diskusia o podstate peňazí a jej tvorbe. Komu by nebol známy medzi ekonómami spor o povahu ponuky peňazí medzi endogénnou exogénnou teóriou. Pri bližšom pohl'ade skrz problém mylného usudzovania $\mathrm{z}$ časti na celok, môžeme dôjst' $\mathrm{k}$ zaujímavému záveru, že $\mathrm{v}$ podstate obidva pohlady sú správne. Záleží už len, z ktorého uhlu sa na danú problematiku pozrieme. Akú hrá úlohu likvidita bankového systému pri tvorbe peňazí „ex nihilo“? Podl'a exogénnej tvorby peňazí rast likvidity, ktorú do systému vloží CB spôsobí úverovú expanziu ${ }^{10}$, ked' obchodné banky mnohonásobne zmultiplikujú získanú likviditu a vytvoria vklady. Podl'a endogénnej tvorby peňazí obchodné banky

${ }^{10}$ Predpokladajme, že existuje dostatočný dopyt po úveroch, primárne sa nám v našom príklade jedná o ponuku peňazí 
nepotrebujú likviditu k zvýšeniu množstva peňazí v ekonomike. ${ }^{11}$ Pri posúdení úlohy likvidity na makroekonomickú úverovú kreáciu môžeme aplikovat' koncept mylného usudzovania z časti na celok. Pre individuálnu obchodnú banku je likvidita potrebná kvôli prípadnému odlivu poskytnutého úveru (vytvoreného vkladu) do inej banky. Obchodná banka potrebuje likviditu z individuálneho hl'adiska k uskutočňovaniu platieb, kvôli výberu obeživa, udržiavaniu PMR atd'. V prípade, že banka zvyšuje úverovú expozíciu, odkial' zoberie prostriedky na odliv úverov?12 Problém obchodných bánk s nedostatkom likvidity je zrejmý pri zamrznutí medzibankového trhu. Obchodné banky s nedostatkom likvidity by svoje likvidné problémy navršovali poskytovaním d'alších úverov a tak môžu výrazne z individuálneho hl'adiska obmedzit' ponuku úverov. Problém s likviditou dostáva iný rozmer v prípade, že sa na vzt'ah medzi likviditou a úvermi pozrieme z makroekonomického hl'adiska. V prípade, že by banka s nedostatkom likvidity odmietla poskytnút' úver kvôli nedostatku likvidity, bonitný subjekt sa môže obrátit' na obchodnú banku s prebytkom likvidity, ktorá z hl'adiska likvidity nie je obmedzená likviditou pri poskytnutí úveru ${ }^{13}$. Z individuálneho hl'adiska bude úver kvôli nedostatku likvidity individuálnej obchodnej banky zamietnutý, ale $z$ makroekonomického pohl'adu bude poskytnutý. Klient jednoducho odíde $\mathrm{k}$ banke $\mathrm{s}$ prebytkom likvidity, ktorá v systéme z daného inštitucionálneho hl'adiska musí existovat'. Keby sme chceli vyvodzovat' závery z individuálneho hl'adiska, potom by došlo $k$ zníženiu úverovej expanzie kvôli nedostatku likvidity obchodnej banky alebo niekolkých obchodných bánk. ${ }^{14}$ Naopak z makroekonomického pohl'adu likvidita pri poskytovaní úverov $\mathrm{v}$ ekonomike ako celku nehrá žiadnu úlohu a nedokáže obmedzit' poskytovanie úverov. ${ }^{15} \mathrm{~V}$ súčasnosti sa do pozornosti hospodárskej politiky dostáva netradičná menová politika $\mathrm{v}$ podobe kvantitatívneho uvol'ňovania. Kvantitatívne uvol'ňovanie $^{16}$ vo forme vtlačenia prebytočnej likvidity nedokáže podporit' úverovú expanziu z makroekonomického hl'adiska prostredníctvom priameho vplyvu na poskytovanie úverov. Prebytočná likvidity v systéme nemá vplyv na množstvo peňazí a následne na d'alšie ekonomické veličiny.

\footnotetext{
11 Správne by sa malo jednat’ o dobrovol'nú likviditu slúžiacu k „poskytovaniu úverov“ obchodnými bankami. Samozrejme obchodné banky v praxi potrebujú likviditu kvôli existencii obeživa a povinných minimálnych rezerv

${ }^{12}$ Banky s nedostatkom likvidity môžu dodatočnú likviditu získat' od OB s prebytkom likvidity, emisiou vlastných cenných papierov alebo od CB

${ }^{13}$ Makroekonomický systém funguje tak, že OB sa svojvol'ne nedokážu zbavit’ systémovej likvidity, na to má monopol CB

14 Bankový systém funguje tak, že iba CB má možnost' menit' množstvo systémovej likvidity v bankovom systéme, obchodné banky ako celok sa jej nedokážu svojvol'ne bez pomoci CB zbavit'. $Z$ toho vyplýva, že pokial' do procesu nezasiahne $C B$, tak odliv likvidity z jednej banky bude znamenat' príliv likvidity do inej banky

${ }_{15}$ Jedná sa o likviditu nad rámec, ktorá slúži k akomodácii dopytu po obežive, udržiavaniu povinných minimálnych rezerv a dobrovol'ných rezerv

16 Problematika kvantitatívneho uvolńnovania je pomerne rozsiahla, ciel'om bolo poukázat' iba na problém mylného usudzovania z časti na celok, ktorý obsahuje politika QE a nie detailne pojednávat'o danej hospodárskej politike
} 


\section{Záver}

Klasická makroekonómia s keynesiánskou sa dostáva do sporu, pretože keynesiánska makroekonómia je postavená na inom metodologickom základe ako klasická makroekonómia. Obidve makroekonómie sa nevylučujú, ale skôr vzájomne dopíňajú, aj ked' vedú medzi sebou doteraz nevyriešené spory. Je potrebné overovat' vždy obsahovú stránku použitej metódy, ktorá nám môže odhalit' problém mylného usudzovania z časti na celok. Problém medzi keynesiánskou makroekonómiou a klasickou je symetrický. Keynesiánska makroekonómia môže l'ahko skĺznut' k mylnému usudzovaniu z celku na jednotlivé časti. Je potrebné znovu otvorit' koncept mylného usudzovania $\mathrm{z}$ časti na celok $\mathrm{v}$ makroekonómii nielen $\mathrm{v}$ praktickej ale i teoretickej ekonómii. Perspektívu vývoja mylného usudzovania z časti na celok vidím napríklad vo využití pre peňažnú teórie, kde nastáva spor o úlohu likvidity medzi endogenistami a exogenistami. Zatial', čo z individuálneho pohl'adu banky je likvidita dôležitá pri poskytovaní úverov z hładiska celkového poskytovania úverov už nemusí hrat' žiadnu úlohu. Podobné perspektívne využitie vidím i pri posudzovaní vplyvu derivátov na makro ekonomiku. Zatial', čo z individuálneho hl'adiska deriváty dokážu znížit' individuálne riziko, z makroekonomického hl'adiska sa riziko nedá znížit' a odstránit' prostredníctvom derivátov, ale iba presunút na iné subjekty, čím sa celkové riziko nemení. Čo platí pre individuálne subjekty, nemusí vždy nutne platit' pre celok. Koncept mylného usudzovania z časti na celok možno považovat' za dostatočne silný argument pre používanie metodického pluralizmu. Metodologický individualizmus a kolektivizmus sa tak môžu v makroekonómii vhodne doplńat'. 


\section{Bibliografie}

\section{KNIŽNÉ MONOGRAFIE}

A. Smith (1776), An Inquiry into the nature and causes of the wealth of nations, electronic version, The Pensylvania state university, 2005, online verzia na http://www2.hn.psu.edu/faculty/jmanis/adam-smith/wealth-nations.pdf

J. S. Mill (1863), Utilitarianism, vydavatel' London Parker, Son and Bourn, online verzia na http://archive.org/details/a592840000milluoft

J. Seger, R. Hindls, S. Hronová (1998), Štatistika v hospodářství, ETC Publishing, 1. Vydání, ISBN 80-86006-56-5

J. Koderová, M. Sojka, J. Havel (2011), Teorie peněz, Wolters Kluwer, 2. Vydání 4/2011, ISBN 978-80-7357-640-0

J.M.Keynes (1936), The general theory of employment, Interest and money, Macmillan Cambridge University press, for Royal Economic society 1936

K. E. Boulding (1950), A Reconstruction of economics, New York: John Wiley\&Sons

M. Friedman (1997), Metodologie pozitivní ekonomie, Grada publishing, (překlad podle anglického originálu Methodology of positive economics, 1979), Liberální institut, Praha 1997, ISBN 80-7169-521-1

M. Loužek (2001), Spor o metodu mezi rakouskou školou a německou historickou školou, Nakladatelstí karolinu, Praha, 2001, první vydání, Univerzita Karlova v Praze, ISBN 80-246-0236-9

M. N. Rothbard (1956), Toward a reconstruction of Utility and Welfare Economics, originally published in On Freedom and Free Enterprise: The Economics of Free Enterprise, May Sennholz, ed. (Princeton, N.J: D. Van Nostrand, 1956), online dostupné $\mathrm{z}$ http:/ /118.97.161.124/perpus-

fkip/Perpustakaan/Libertarian\%20Study/Artikel/toward.pdf

M. Sojka (2010), Dejiny ekonomických teórií, Havlíček Brain Team, 1. Vydání, ISBN 978-80-87109-21-2

P. Krugman (2012), Skoncovat s krizí (z originálu End this depression now!), Vyšehrad, 2012, ISBN 978-80-7429-294-1

R. C. Koo (2008), The holy grail of macroeconomics, lessons from Japan's great stagnation, John Wiley\&Son (Asia), ISBN 974-0470-82387-3 
T. R. Jain, O. P. Khana (2006), Neekunj print process, Delhi, ISBN 81-88597-18-X, online verzia,

http:/ / books.google.cz/books?id=DyrqBToCDgQC\&printsec=frontcover\&hl=cs\& source $=$ gbs_ge_summary_r\&cad $=0 \# \mathrm{v}=$ onepage\&q\&f=false

\section{PRÍSPEVKY V MONOGRAFICKÉ LITERATÚRE}

L. R. Wray (1997), Kenneth Boulding's reconstruction of macroeconomics, Review of Social economy, Vol. LV No. 4 Winter 1997, The association for social economics, ISSN 0034-6764, http:/ / www.tandfonline.com/doi/pdf/10.1080/00346769700000017

M. N. Rothbard (1956), Toward a reconstruction of Utility and Welfare Economics, originally published in On Freedom and Free Enterprise: The Economics of Free Enterprise, May Sennholz, ed. (Princeton, N.J: D. Van Nostrand, 1956), online dostupné z http:/ /118.97.161.124/perpus-

fkip/Perpustakaan/Libertarian\%20Study/Artikel/toward.pdf

\section{VÝZKUMNÉ ZPRÁVY}

G. Eggertsson (2010), Paradox of toil, Federal reserve bank of New York, Staff report no. 433, February 2010,

http://www.newyorkfed.org/research/staff_reports/sr433.pdf

G. Eggertsson, P. Krugman, (2011), Debt, Deleveraging, and the liquidity trap, 2. Vydání, 2/14/2011, New York, Federal reserve bank of New York and Princeton University,

http://www.princeton.edu/ pkrugman/debt_deleveraging_ge_pk.pdf

J. Mayer (2003), The fallacy of composition: a review of the literature, Trade and development report 2002, United Nations conference of trade and development, The World Economy, Vol. 25 (6), http:/ / unctad.org/en/docs/osgdp20031_en.pdf

L. R. Wray (2006), Teaching the fallacy of composition: The Federal budget deficit, CEEPS, Policy Note 06/01, March 27, 2006, University of Missouri, http://current.com/1n2h2kc

W. L. Rowe (1962), The fallacy of composition, Mind, New Series, Vol. 71. No. 281, Jan. 1962, pp. 87-92, Oxford University Press on behalf ot the mind Association, www.jstor.org/stable/2251735

W. A. Kerr (2009), Recession, International trade and the fallacies of composition, The Estey centre journal of international law and trade policy, vol. 10 number 1, p. 1 - 11, ISSN 1496-5208, 
http:/ / dspace.cigilibrary.org/jspui/bitstream/123456789/25193/1/Recession, \%2 OInternational $\% 20$ Trade $\% 20$ and $\% 20$ the $\% 20$ Fallacies $\% 20$ of $\% 20$ Composition.pdf?1

\section{ČLÁNKY V ČASOPISOCH}

R.C.Koo (2001), The Japanese economy in balance sheet recession, The real culprit is fallacy of composition, not complacency, Nomura research institute, Tokyo and Waseda U, Bussines Economics, April 2001, v. 36, issue 2, pp. 15-23, http:/ / web.ebscohost.com.ezproxy.vse.cz/ehost/pdfviewer/pdfviewer?sid=e313 6561-f855-451f-a2a3-53d527cd747d\%40sessionmgr10\&vid=8\&hid=9

\section{INTERNETOVÉ ZDROJE}

B. Mitchell (2010) Fiscal austerity - the newest fallacy of composition, July 6, 2010, http:/ / bilbo.economicoutlook.net/blog/?p=10547 


\section{E-LOGOS}

ELECTRONIC JOURNAL FOR PHILOSOPHY

Ročník/Year: 2013 (vychází průběžně/ published continuously)

Místo vydání/Place of edition: Praha

ISSN 1211-0442

Vydává/Publisher:

Vysoká škola ekonomická v Praze / University of Economics, Prague

nám. W. Churchilla 4

Czech Republic

13067 Praha 3

IČ: 61384399

Web: http://e-logos.vse.cz

Redakce a technické informace/Editorial staff and technical information:

Miroslav Vacura

vacuram@vse.cz

Redakční rada/Board of editors:

Ladislav Benyovszky (FHS UK Praha, Czech Republic)

Ivan Blecha (FF UP Olomouc, Czech Republic)

Martin Hemelík (VŠP Jihlava, Czech Republic)

Angelo Marocco (Pontifical Athenaeum Regina Apostolorum, Rome, Italy)

Jozef Kelemen (FPF SU Opava, Czech Republic)

Daniel Kroupa (ZU Plzeň, Czech Republic)

Vladimír Kvasnička (FITT STU Bratislava, Slovak Republic)

Jaroslav Novotný (FHS UK Praha, Czech Republic)

Jakub Novotný (VŠP Jihlava, Czech Republic)

Ján Pavlík (editor-in-chief) (VŠE Praha, Czech Republic)

Karel Pstružina (VŠE Praha, Czech Republic)

Miroslav Vacura (executive editor) (VŠEE Praha, Czech Republic) 